\title{
Editorial
}

\section{DESENVOLVIMENTO SUSTENTÁVEL: a utopia possível ?}

Os que gostam de romancear a história do ambientalismo dizem que a formulação do conceito de desenvolvimento sustentado, que aparece pela primeira vez no relatório da Comissão Brundtland em 1987 , baseou-se no dito popular africano"Nós não herdamos a Terra de nossos pais nós a emprestamos de nossos filhos". Outros postulam que o conceito é uma evolução do termo ecodesenvolvimento, utilizado por Maurice Strong em 1973, na primeira reunião do Programa das Nações Unidas para o Meio Ambiente (PNUMA), e posteriormente definido por lgnacy Sachs em 1974 no clássico "Environnement et styles de développement" (Sachs, 1986).

De qualquer forma, é inegável que, nas últimas três décadas, centenas de especialistas se envolveram na discussão teórica e conceitual do termo, que rapidamente passou de sustentado para sustentável, com a clássica definição dada pela Comissão para o Desenvolvimento Sustentável da ONU - desenvolvimento sustentável é aquele que atende às necessidades do presente sem comprometer a possibilidade das gerações futuras atenderem as suas próprias necessidades (http://www.un.org/esa/sustdev/). A expressão ganhou status suficiente para adjetivar a Rio + 10, realizada em Joanesburgo em agosto de 2002, (Conferência das Nações Unidas sobre o Desenvolvimento Sustentável), e passou a ser um dos jargões mais utilizados pela mídia.

Nos últimos trinta anos discutiu-se acirradamente a fundamentação teórica do conceito de desenvolvimento sustentável. Em um rápido levantamento nas bases de dados disponíveis "on line" acharemos centenas de documentos, teses e artigos que abordam esta temática. Infelizmente, a evolução conceitual e teórica não foi acompanhada pela prática. As experiências bem sucedidas de utilização sustentável de um recurso natural invariavelmente esbarram na questão da escala.

Pouquíssimas são as experiências documentadas de práticas onde, de fato, o uso sustentável dos recursos naturais gera ou mantém o desenvolvimento econômico, social e/ou cultural de grupos e/ou comunidades que extrapolem umas poucas dezenas de famílias. Exemplos considerados paradigmáticos, como o do ecoturismo na região de Bonito/MS, não resistem a uma avaliação mais criteriosa como mostra o Ponto de Vista deste número da BIOTA NEOTROPICA.

Contrapondo-se ao inevitável pessimismo resultante destas constatações, a consolidação e o sucesso do Programa BIOTA/FAPESP, teimosamente, insistem em reafirmar diariamente que o esforço coletivo transforma a utopia em realidade. $A$ implantação da Rede Biota de Bioprospecção e Bioensaios/RedeBio (http://www.redebio.org.br), é apenas mais uma etapa deste processo de transformação.

A meta da RedeBio é integrar os grupos de pesquisa que atuam nas várias etapas da prospecção de compostos orgânicos de interesse econômico, tendo como premissa que um percentual dos royalties, oriundos da comercialização de produtos resultantes da pesquisa desenvolvida no âmbito da rede, seja obrigatoriamente investido na infraestrutura de conservação in situ do Estado de São Paulo. Com a criação desta rede o Programa BIOTA/FAPESP dá um passo importante, pois, através da bioprospecção, o Programa poderá gerar os recursos e contribuir para a criação dos mecanismos 
econômicos necessários para a viabilizar a conservação da biodiversidade. Esta é uma forma indireta de assegurar o uso sustentável deste inestimável patrimônio, mas talvez seja através de formatos inovadores deste tipo que vamos encontrar os mecanismos para transformar a conservação no sustentáculo de um novo modelo econômico. E, novamente, a utopia se transformaria em realidade!

\section{Carlos Alfredo Joly}

Corrdenador do Programa Biota/Fapesp

- COMISSÃO MUNDIAL SOBRE MEIO AMBIENTE E DESENVOLVIMENTO

(CMMAD) 1988. Nosso futuro comum. Rio de Janeiro, Fundação Getulio Vargas, 430 p.

- SACHS, I. 1974. Environnement et styles de développement. Annales 3: 533-570.

- SACHS, I. 1986. Ecodesenvolvimento: crescer sem destruir. São Paulo, Vértice, 280 $\mathrm{p}$ 